\title{
Effect of Elevated Temperature on Growth and Ribonucleic Acid Synthesis in Cryptococcus albidus
}

\author{
By DEAN A. STETLER AND GEORGE BOGUSLAWSKI \\ Department of Microbiology, University of Kansas, Lawrence, \\ Kansas 66045, U.S.A. \\ AND CHARLES J. DECEDUE \\ The Enzyme Laboratory, University of Kansas
}

(Received 8 December 1977)

\begin{abstract}
When a growing culture of Cryptococcus albidus was shifted from 27 to $37^{\circ} \mathrm{C}$, growth ceased abruptly and the cells died rapidly (over $90 \%$ after $4 \mathrm{~h}$ ). The temperature shift resulted in a rapid cessation of $\left[{ }^{3} \mathrm{H}\right]$ uridine incorporation (as perchloric acid-insoluble material). DEAESephadex chromatography of crude extract from $C$. albidus cells revealed the presence of two major enzyme fractions with RNA polymerase activity. The fractions were insensitive to $\alpha$-amanitin, and both synthesized RNA efficiently at $23{ }^{\circ} \mathrm{C}$ but not at $37^{\circ} \mathrm{C}$. Neither proteolytic digestion of the enzymes nor ribonuclease degradation of the RNA products could account for the observed decline in RNA synthesis at the elevated temperature.
\end{abstract}

\section{INTRODUCTION}

The yeast Cryptococcus albidus is classified as a non-pathogenic member of the genus Cryptococcus, partly on the basis of nutritional requirements and partly on the basis of its inability to grow at $37^{\circ} \mathrm{C}$ (Emmons et al., 1977). A number of reports have described the effects of the elevated temperature on whole cells of various cryptococci (Dabbagh et al., 1974; Tang \& Howard, 1973), but macromolecular synthesis in cell-free systems has not been investigated. In this communication we present evidence that RNA synthesis in Cryptococcus albidus strain CR 172108 is severely restricted by a temperature shift from 23 to $37^{\circ} \mathrm{C}$. Both crude extract and individual RNA polymerases exhibit the same pattern of inhibition. The cessation of RNA synthesis in vitro is paralleled by the cessation of growth and uridine incorporation in vivo.

\section{METHODS}

Organism. Cryptococcus albidus (strain CR172108) was obtained from Dr Geoffrey Land (Wadley Institute. Dallas, Texas, U.S.A.). The media used for the cultivation of the fungus were described previously (Dabbagh et al., 1974). Growth was measured in a Spectronic 20 (Bausch and Lomb) colorimeter at $420 \mathrm{~nm}$, and by viable cell count on Sabouraud agar plates as previously described (Dabbagh et al., 1974).

Chemicals. Unlabelled ribonucleoside triphosphates and calf thymus DNA (type I) were purchased from Sigma; $\left[{ }^{3} \mathrm{H}\right]$ UTP $\left(25 \mathrm{Ci} \mathrm{mmol}^{-1}\right)$ was from New England Nuclear Corporation; $\left[{ }^{3} \mathrm{H}\right]$ uridine $\left(25 \mathrm{Ci} \mathrm{mmol}^{-1}\right)$ was from Schwarz/Mann, Orangeburg, New Jersey, U.S.A.; Sephadex G-25 and DEAE-Sephadex A25 were from Pharmacia; and $\alpha$-amanitin was from Boehringer.

Extraction and assay for RNA polymerase. Cells were grown in 101 complex medium (Dabbagh et al., 1974) for $33 \mathrm{~h}$ at $27^{\circ} \mathrm{C}$, harvested by centrifugation and washed with distilled water (total yield $40 \mathrm{~g}$ wet weight). The soluble fraction (high-speed enzyme, HSE) was obtained as described previously (Boguslawski et al., 1974). RNA polymerase activity was assayed at either 23 or $37^{\circ} \mathrm{C}$ under otherwise standard conditions (Boguslawski et al., 1977) using [ $\left.{ }^{3} \mathrm{H}\right] \mathrm{UTP}$ as labelled RNA precursor.

DEAE-Sephadex chromatography. DEAE-Sephadex A25 was washed and equilibrated with the standard 

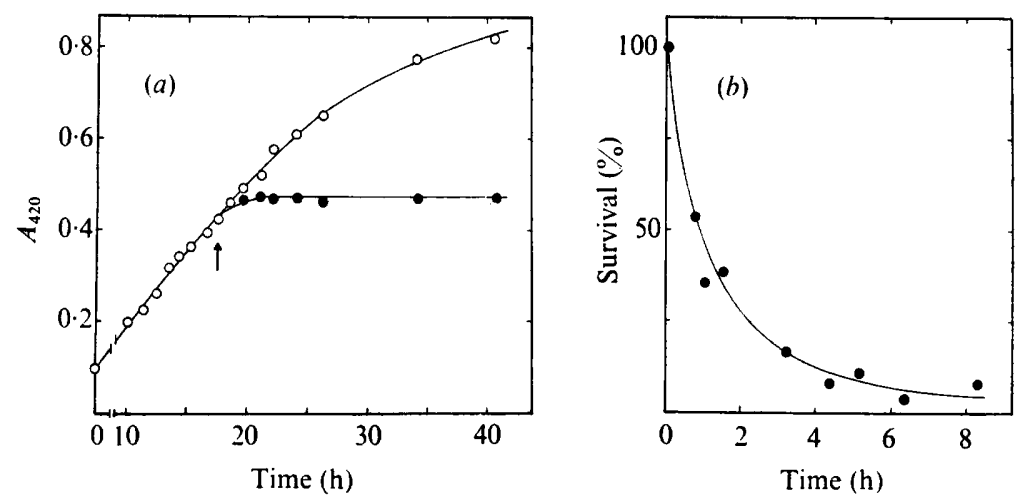

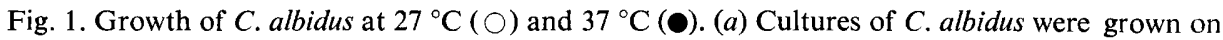
minimal medium (Dabbagh et al., 1974) in triple-baffled flasks with side arms (Bellco) at $27^{\circ} \mathrm{C}$. At the indicated time (arrow), one culture was transferred to a waterbath shaker at $37^{\circ} \mathrm{C}$ and incubation was continued. (b) Decline in cell viability upon incubation at $37^{\circ} \mathrm{C}$ (the initial cell count was $8 \cdot 5 \times 10^{5}$ cells $\mathrm{ml}^{-1}$ ).

buffer as described by Roeder \& Rutter (1969), except that $\mathrm{MgCl}_{2}$ was omitted. A sample of HSE was applied to the column at a rate of about 0.5 column vol. $h^{-1}$. The column was washed with the same buffer and the activity was eluted with a linear gradient of 7 column vol. of 0.05 to $0.42 \mathrm{M}$-ammonium sulphate in the standard buffer. The active fractions were pooled and stored at $-70{ }^{\circ} \mathrm{C}$.

Ribonuclease activity. Degradation of RNA was monitored using ${ }^{3} \mathbf{H}$-labelled total yeast RNA. The RNA was prepared by growing Saccharomyces cerevisiae in the presence of $\left[{ }^{3} \mathrm{H}\right]$ uridine and extracting RNA with phenol. Radioactive RNA was mixed with the fractions tested for ribonuclease activity and incubated at the appropriate temperature. At specified times, samples $(100 \mu \mathrm{l})$ of the mixtures were removed and pipetted on to DEAE-cellulose filter discs (DE81, Whatman). The discs were then processed as described by Roeder (1974) for the determination of radioactivity. Control experiments with ribonuclease A (Sigma) showed over $99 \%$ degradation of the RNA in 60 min at $23{ }^{\circ} \mathrm{C}$.

Other procedures. The incorporation of $\left[{ }^{3} \mathrm{H}\right]$ uridine into whole cells was followed as previously described (Dabbagh et al., 1974). The concentration of $\left(\mathrm{NH}_{4}\right)_{2} \mathrm{SO}_{4}$ in column fractions was measured with a Radiometer (Copenhagen, Denmark) conductivity meter CDM 2e. Protein was determined by the method of Lowry et al. (1951).

\section{RESULTS}

\section{Growth of C. albidus at 27 and $37^{\circ} \mathrm{C}$ and incorporation of $\left[{ }^{3} \mathrm{H}\right]$ uridine}

In partial agreement with the findings of other investigators (Dabbagh et al., 1974; Tang \& Howard, 1973), our data (Fig. 1 a) show that a shift from the permissive $\left(27^{\circ} \mathrm{C}\right)$ to the non-permissive $\left(37^{\circ} \mathrm{C}\right)$ environment resulted in an abrupt cessation of growth. The cessation of growth was followed by rapid cell death (Fig. $1 \mathrm{~b}$ ), so that $90 \%$ of the cells died within $4 \mathrm{~h}$ after the shift. No substantial morphological change or cell lysis was observed at $37^{\circ} \mathrm{C}$, but there was an initial slight increase in turbidity.

The inhibition of growth at the elevated temperature was not due to a decrease in protein synthesis as measured by incorporation of $\left[{ }^{14} \mathrm{C}\right]$ isoleucine (data not shown). However, when $\left[{ }^{3} \mathrm{H}\right]$ uridine incorporation into perchloric acid (PCA)-insoluble material was tested (Fig. 2), it appeared that the shift to $37^{\circ} \mathrm{C}$ resulted in the cessation of incorporation of radioactivity. This could be partially explained by an increase in ribonucleolytic activity at $37^{\circ} \mathrm{C}$ and/or by lower permeability of the cells to uridine. Alternatively, it was possible that RNA synthesis was affected by the temperature rise. Therefore a cell-free extract (high-speed enzyme, HSE) was prepared and RNA polymerase activity was tested at 23 and $37^{\circ} \mathrm{C}$. 


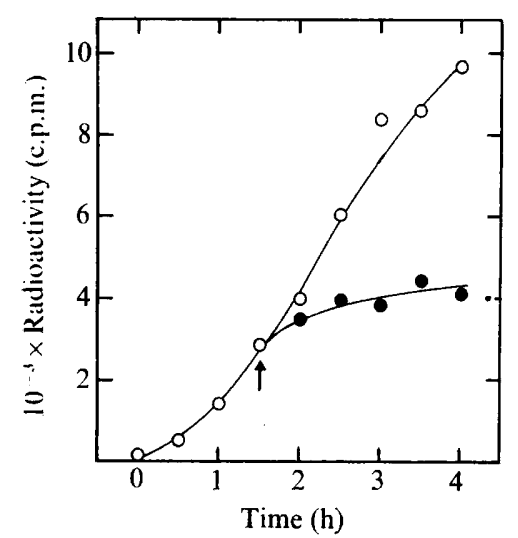

Fig. 2

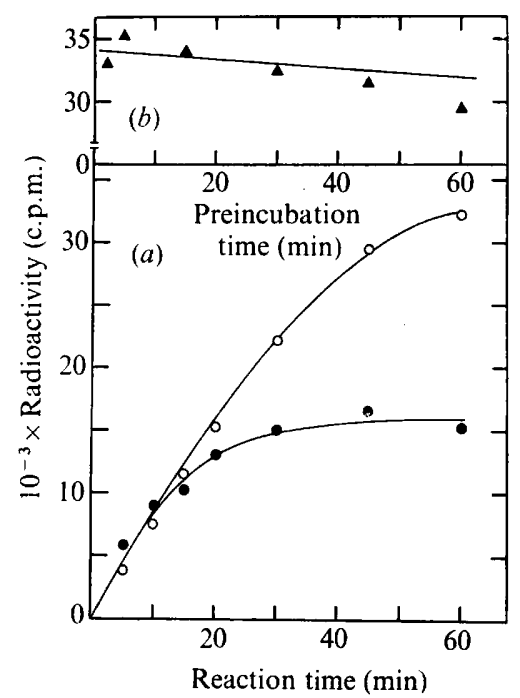

Fig. 3

Fig. 2. Incorporation of $\left[{ }^{3} \mathrm{H}\right]$ uridine into whole cells at $27^{\circ} \mathrm{C}(\mathrm{O})$ and $37{ }^{\circ} \mathrm{C}(\bullet)$. Cells were grown on minimal medium (Dabbagh et al., 1974) at $27^{\circ} \mathrm{C}$ to an absorbance of $0 \cdot 19$ at $420 \mathrm{~nm}$. At that time (time zero on the graph), $50 \mu \mathrm{Ci}$ of $\left[{ }^{3} \mathrm{H}\right.$ ]uridine and $12 \mu \mathrm{mol}$ of unlabelled uridine carrier were added to a $50 \mathrm{ml}$ culture and incorporation was allowed to proceed for $1.5 \mathrm{~h}$. A portion of the culture was then transfered (arrow) to $37^{\circ} \mathrm{C}$ and incubation continued for $2.5 \mathrm{~h}$. Samples ( $1 \mathrm{ml}$ ) were taken and radioactivity was determined as described in Methods.

Fig. 3. Effect of temperature on RNA polymerase activity. (a) High-speed enzyme (HSE) (52.5 $\mu \mathrm{g}$ protein) was assayed for $60 \mathrm{~min}$ as described in Methods at $23{ }^{\circ} \mathrm{C}(\mathrm{O})$ and $37^{\circ} \mathrm{C}(\bullet)$. (b) HSE was preincubated at $37^{\circ} \mathrm{C}$ and at various times samples $(52.5 \mu \mathrm{g}$ protein) were taken and assayed for polymerase activity at $23^{\circ} \mathrm{C}(\boldsymbol{\Delta})$ for $60 \mathrm{~min}$. In all assays, the $\left(\mathrm{NH}_{4}\right)_{2} \mathrm{SO}_{4}$ concentration was $0.046 \mathrm{M}$.

\section{RNA synthesis in vitro}

The incorporation of $\left[{ }^{3} \mathrm{H}\right] \mathrm{UMP}$ into RNA continued for at least $60 \mathrm{~min}$ at $23{ }^{\circ} \mathrm{C}$ (Fig. $3 a$ ). In contrast, the incorporation at $37^{\circ} \mathrm{C}$ was halted in less than $30 \mathrm{~min}$. However, the preincubation of $\mathrm{HSE}$ at $37^{\circ} \mathrm{C}$ for up to $60 \mathrm{~min}$ and subsequent assay at $23{ }^{\circ} \mathrm{C}$ did not decrease $\left[{ }^{3} \mathrm{H}\right]$ UMP incorporation (Fig. $3 b$ ). Thus, the enzyme itself is not permanently damaged at the elevated temperature.

It was of interest to know whether the temperature sensitivity was a property of one or more RNA polymerase forms; therefore, a sample of HSE was fractionated on a DEAESephadex column (Fig. 4). Two well-separated fractions with activity were seen, one eluting at an ammonium sulphate concentration of about $0 \cdot 10 \mathrm{M}$ (enzyme I), and the other at about $0 \cdot 18$ to $0.23 \mathrm{M}$ (enzyme II). On the basis of their positions of elution, these fractions probably correspond to the known eukaryotic RNA polymerases I and II (Jacob, 1973). Strikingly, however, neither of the enzymes showed any sensitivity to the fungal toxin $\alpha$-amanitin, even at a toxin concentration of $80 \mu \mathrm{g} \mathrm{ml}^{-1}$. This is consistent with the observation that growth of C. albidus is not inhibited by $\alpha$-amanitin, nor is incorporation of $\left[{ }^{3} \mathrm{H}\right]$ uridine into RNA affected by the drug (data not shown).

The enzymes I and II were tested for activity at 23 and $37^{\circ} \mathrm{C}$. Both RNA polymerases behaved exactly like the HSE preparation (Fig. 3). It was possible, however, that the observed apparent cessation of RNA synthesis at $37^{\circ} \mathrm{C}$ was due to contaminating ribonucleolytic activity present in the enzyme fractions. To test this possibility, the two enzymes were mixed with $\left[{ }^{3} \mathrm{H}\right]$ uridine-labelled yeast RNA and incubated at 23 and $37^{\circ} \mathrm{C}$ for $60 \mathrm{~min}$. Samples of the mixtures were taken at various times and the amount of RNA remaining was determined. At the same time, standard RNA polymerase assays were performed with enzymes I and II to determine the extent of RNA synthesis. The results (Fig. 5) show the 


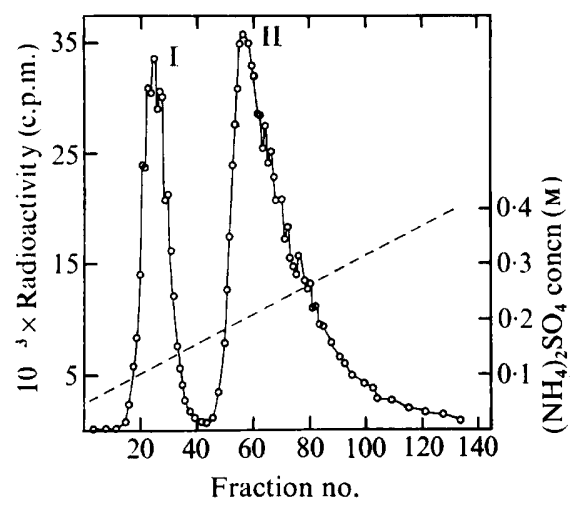

Fig. 4

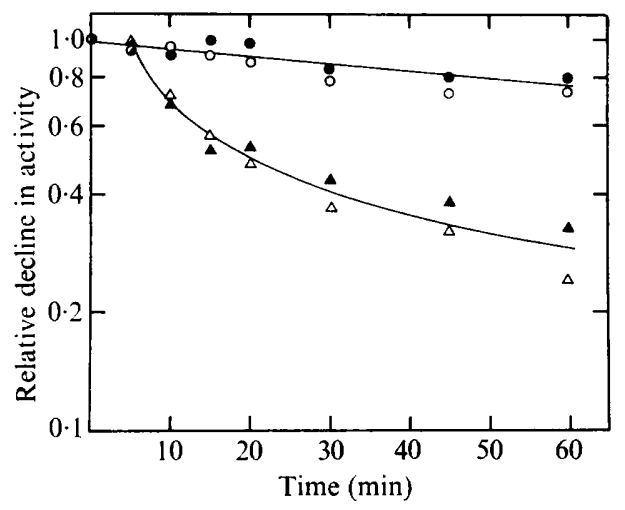

Fig. 5

Fig. 4. DEAE-Sephadex chromatography of high-speed enzyme (HSE). HSE (49 mg protein) was applied to a column $(0.95 \times 7 \mathrm{~cm})$ equilibrated with the standard buffer and the column was washed and developed with a $140 \mathrm{ml}$ gradient of 0.05 to $0.42 \mathrm{M}-\left(\mathrm{NH}_{4}\right)_{2} \mathrm{SO}_{4}$ in the same buffer (---). Fractions $(1 \mathrm{ml})$ were collected and $1 \mathrm{mg}$ bovine serum albumin was added to each. Samples $(50 \mu \mathrm{l})$ were assayed for RNA polymerase activity $(O)$ for $60 \mathrm{~min}$ at $23{ }^{\circ} \mathrm{C}$ under standard conditions.

Fig. 5. RNA polymerase activity and ribonucleolytic degradation catalysed by enzyme fractions I and II. RNA polymerase activity in enzyme fractions I $(\triangle)$ and II $(\Delta)$ was assayed at $0.05 \mathrm{M}$ $\left(\mathrm{NH}_{4}\right)_{2} \mathrm{SO}_{4}$ at 23 and $37{ }^{\circ} \mathrm{C}$ under otherwise standard conditions. Incorporation of [ ${ }^{3} \mathrm{H}$ ] UMP into RNA was measured at the indicated times. The ratios of incorporation at $37^{\circ} \mathrm{C}$ to incorporation at $23{ }^{\circ} \mathrm{C}$ were calculated and the values for the $5 \mathrm{~min}$ points were taken as 1.0 . Ribonucleolytic activity was determined for the two enzyme fractions as described in Methods. The added ${ }^{3} \mathrm{H}$-labelled RNA (time zero) for enzyme I $(\bigcirc)$ represented 7500 c.p.m. $\left(23{ }^{\circ} \mathrm{C}\right)$ and 8000 c.p.m. $\left(37^{\circ} \mathrm{C}\right)$. The ratio $(8000 / 7500)$ was taken as $1 \cdot 0$. The added RNA for enzyme II (O) represented 7670 c.p.m. $\left(23^{\circ} \mathrm{C}\right)$ and 6730 c.p.m. $\left(37^{\circ} \mathrm{C}\right)$. The ratio $(6730 / 7670)$ was taken as $1 \cdot 0$. The incubations were carried out in the complete RNA polymerase assay systems except that $\left[{ }^{3} \mathrm{H}\right] \mathrm{UTP}$ was replaced by the equivalent amount of unlabelled UTP.

relative decline in the amount of added ${ }^{3} \mathrm{H}$-labelled RNA and the relative decline in the RNA polymerase activity in the course of the experiment. The data are presented as normalized ratios of polymerase activity or RNA degradation at $37^{\circ} \mathrm{C}$ to the corresponding activity at $23^{\circ} \mathrm{C}$. In this manner a correlation is obtained between RNA polymerase and ribonuclease activities observed at both 23 and $37{ }^{\circ} \mathrm{C}$. It is apparent that both enzymes were equally sensitive to elevated temperature and that the slight contaminating ribonuclease activity could not be responsible for the observed cessation of RNA synthesis at $37^{\circ} \mathrm{C}$. Because saturating amounts of DNA template were used in the assays, a deoxyribonuclease activity could also be discounted. Identical results were obtained with the HSE preparation (not shown).

\section{DISCUSSION}

Our results show that growth and uptake of an RNA precursor by C. albidus was halted when cells were shifted from 27 to $37^{\circ} \mathrm{C}$. An adequate explanation for this phenomenon was provided by the observed inhibition of RNA synthesis in vitro at the non-permissive temperature. This contrasts, however, with an earlier report (Tang \& Howard, 1973) in which only little effect on RNA synthesis could be seen. Perhaps this discrepancy is due to the difference in viabilities of the strains used. Incubation of our strain for $4 \mathrm{~h}$ at $37^{\circ} \mathrm{C}$ resulted in the death of over $90 \%$ of the cells as measured by viable cell count. In contrast, Tang \& Howard (1973) showed that with their strain even $18 \mathrm{~h}$ incubation left about $90 \%$ of the cells alive. This was determined by the eosin dye exclusion technique which may account in part for the disparity of the results. Further complication is added by the report of Dabbagh et al. (1974) who found that cells of various species of saprophytic cryptococci, including C. albidus, lysed soon after the temperature shift. Neither we nor Tang \& Howard (1973) observed cell lysis within the $37^{\circ} \mathrm{C}$ incubation period used. 
In agreement with the in vivo data, RNA synthesis in the crude preparation (HSE) and in fractionated RNA polymerases from our strain of C. albidus was restricted at $37{ }^{\circ} \mathrm{C}$. Our results demonstrate that this restriction was not due to increased RNA degradation. A possibility that proteolytic enzymes may damage the enzyme during incubation at $37{ }^{\circ} \mathrm{C}$ could also be discounted because full activity was restored as soon as the temperature was lowered to $23{ }^{\circ} \mathrm{C}$. This phenomenon is similar to that described previously for RNA polymerase PC I from Histoplasma capsulatum (Boguslawski et al., 1974). The molecular basis for the temperature effect is at present unknown but it is possible that the enzyme's ability for chain elongation or reinitiation decreased with prolonged incubation at $37^{\circ} \mathrm{C}$. It remains to be seen whether other cryptococci, especially C. neoformans (capable of growth at $37^{\circ} \mathrm{C}$ ), possess a temperature-insensitive RNA polymerase.

The two enzyme fractions obtained from DEAE-Sephadex seem to correspond to eukaryotic RNA polymerases I and II; however, neither of them was inhibited by $\alpha$-amanitin. No sensitivity to the toxin could be detected in HSE or any other subfraction of the total cell homogenate (data not shown). An identical extraction procedure applied to $H$. capsulatum (yeast form) or to $S$. cerevisiae cells yielded RNA polymerase preparations which were inhibited by about $70 \%$ by $\alpha$-amanitin (Boguslawski et al., 1974, and unpublished data). Thus, it seems unlikely that the $\alpha$-amanitin-sensitive RNA polymerase was selectively lost during the course of extraction. Furthermore, although rare, the lack of sensitivity to the toxin is not unique among eukaryotes and has been demonstrated previously in Rhizopus stolonifer spores (Gong \& Van Etten, 1972), and in the mycelial form of $H$. capsulatum (Boguslawski et al., 1975; McMillian et al., 1977).

In summary, our observations show that RNA synthesis in C. albidus is severely restricted at $37{ }^{\circ} \mathrm{C}$. This is sufficient to account for the cessation of growth, but other factors may be involved in the rapid cell death. Although our results are in conflict with the data of others (Dabbagh et al., 1974; Tang \& Howard, 1973), this may be due to differences between strains. The available strains of $C$. albidus are not well characterized genetically, and variations are possible. It is only recently that the existence of the perfect state of $C$. neoformans has been firmly established (Kwon-Chung, 1975). If, as suggested by Van der Walt (1967), C. albidus also produces the sexual state, the genetic analysis and comparison of the strains will become feasible.

This work was supported by grant PCM76-14728 from the National Science Foundation, and by grants from the Research Corporation (Brown-Hazen Fund), and from Eli Lilly and Company to G.B. Additional support was provided by the Biomedical Sciences Support Grant RR-07037 to C.J.D. One of us (C.J.D.) wishes to thank Professor R. O. Burns of Duke University for introduction to this project. We thank D. Paretsky and H. Stone for reading the manuscript and $\mathrm{R}$. Eussen for technical assistance.

\section{REFERENCES}

Boguslawski, G., Schlessinger, D., Medoff, G. \& Kobayashi, G. (1974). Ribonucleic acid polymerases of the yeast phase of Histoplasma capsulatum. Journal of Bacteriology 118, 480-485.

Boguslawski, G., Medoff, G., Schlessinger, D. \& Kobayashi, G.S. (1975). Histin, an RNA polymerase inhibitor isolated from Histoplasma capsulatum. Biochemical and Biophysical Research Communications 64, 625-632.

Boguslawski, G., Zehring, W. A., Meyer, R. R. \& PARR, J. S. (1977). Characterization of a novel ribonucleotide-polymerizing enzyme from a fungus, Histoplasma capsulatum. Journal of Biological Chemistry 252, 4337-4346.

Dabbagh, R., Conant, N. F., Nielsen, H. S. \&
BuRns, R. O. (1974). Effect of temperature on saprophytic cryptococci: temperature-induced lysis and protoplast formation. Journal of General Microbiology 85, 177-189.

Emmons, C. W., Binford, C. H., UTz, J.P. \& Kwon-Chung, K. J. (1977). Medical Mycology, 3rd edn, p. 226. Philadelphia: Lea and Febiger.

Gong, C.-S. \& Van EtTen, J. L. (1972). Changes in soluble ribonucleic acid polymerases associated with the germination of Rhizopus stolonifer spores. Biochimica et biophysica acta 272, 44-52.

JACOB, S. T. (1973). Mammalian RNA polymerases. Progress in Nucleic Acid Research and Molecular Biology 13, 93-126.

Kwon-ChunG, K. J. (1975). Description of a new 
genus, Filobasidiella, the perfect stage of Cryptococcus neoformans. Mycologia 67, 1197-1200.

Lowry, O. H., Rosebrough, N. J., FArr, A. L. \& RANDALL, R. J. (1951). Protein measurement with the Folin phenol reagent. Journal of Biological Chemistry 193, 265-275.

McMillian, R., Kumar, B. V., Medoff, G. \& KoBAYASHI, G.S. (1977). Abstracts of the $77 \mathrm{th}$ Annual Meeting, American Society for Microbiology, May, 1977, abstract F60, p. 128.

Roeder, R. G. (1974). Multiple forms of deoxyribonucleic acid-dependent ribonucleic acid polymerase in Xenopus laevis. Journal of Biological Chemistry 249, 241-248.
Roeder, R. G. \& Rutter, W. J. (1969). Multiple forms of DNA-dependent RNA polymerase in eukaryotic organisms. Nature, London 224, 234 237.

TANG, S. L. \& HowARD, D. H. (1973). Metabolism, macromolecular synthesis, and nuclear behavior of Cryptococcus albidus at $37 \mathrm{C}$. Journal of Bacteriology 115, 574-581.

VAN DER WALT, J. P. (1967). Sexually active strains of Candida albicans and Cryptococcus albidus. Antonie van Leeuwenhoek 33, 246-256. 